\title{
OSEANOGRAFI FISIKA PERAIRAN TELUK AMURANG MENURUT PERIODE UMUR BULAN
}

\author{
(Physical Oceanography of Amurang Gulf Waters in Pulation to Lunar Sycle) \\ Janny Franka Polii ${ }^{1}$ \\ ${ }^{1}$ Fakultas Perikanan dan Ilmu Kelautan Universitas Sam Ratulangi, Manado, Sulawesi Utara
}

\begin{abstract}
Changes in the condition of coastal waters in accordance with the phenomenon of tides, waves and currents are dynamic at any time. Research objectives were 1) to measure and analyze the tide conditions of Amurang Bay with different moon period; 2) to know and analyze the characteristies of currents near the coast and waves with moon period in the sky. Results showed that in Kawangkbang Bawah, the surface currents at new moon and quarter 1 moved northwest, full moon moved north northwest, and quater 3 to southeast, respectively. In Matani, surface currents at new moon moved to east southeast, quarter 1 to north northeast, full moon to west northwest, and quarter 3 to west southwest, respectively. The total wave energy in Kawangkoan Bawah was 0.406 joule at new modn, 0.7 joule at quarter $1,0.163$ joule at full moon, and 2.12 joule at quarter, respectively. It was, in Matani, 1.28 joule at new moon, 3.35 joule at quarter $1,1.4$ joule at full moon, and 3.16 joule at quarter 3 , respectively. The tides showed mix semi-diurnal.
\end{abstract}

Keywords: Amurang bay, current, wave, tidal, wind.

Perubahan kondisi perairan pesisir sesuai dengan fenomena pastut, gelombang dan arus dinamis setiap saat. Tujuan riset adalah 1) mengukur dan menganalisis keadaan pasut dari Teluk Amurang sesuai periode umur bulan; 2) mengetahui dan menganalisis karaktertstik arus pantai dan gelombang sesuai periode umur bulan. Hasil menunjukkan bahwa di Kawanghoan Bawah, arus permukaan pada bulan mati dan perbani awal bergerak ke arah barat laut, purnamake utard barat laut, dan perbani akhir ke tenggara. Di Matani, arus permukaan pada bulan mati bergerak ke arah timur tenggara, perbani awal ke ke utara barat laut, purnama ke barat barat laut, dan perbani,akhir ke barat barat daya. Total energi gelombang di Kawangkoan Bawah adalah 0,406 joule pada bulan mati, 0,7 joule pada perbani awal, 0,163 joule pada bulan purnama dan 2,12 joule pada perbani akhir Di Matani, total energi gelombang adalah 1,28 joule pada bulan mati, 3,35 joule pada perbani awat, 1,4 joule pada bulan purnama, dan 3,16 joule pada perbani akhir. Hasil pengukuran pasut metunjukkan tipe campuran atau ganda condong semidiurnal harian.

Kata kunci: Teluk Amurang, arus getombang, pasut, angin.

\section{PENDAHULUAN}

Perairan laut pesisir Minahasa Selatan umumnya dipengauphi oleh iklim global. Massa air arus lintas Indonesia mencapai puncaknya yaitu Juni sampari dengan Agustus, arus laut mencapai puncaknya yaitu bertepatan dengan Monsoon Timur (Southeast Monsoon dan dikenal sebagai musim selatan). Pantai adalah daerah bertemunya daratan dan lautan. Pantai lazimnya menggambarkan sebagian proses laut seperti pasut atau pun arus (Manengkey, 2010).

Secara umum arus di perairan pantai digerakkan oleh pasut, angin dan gelombang. Dorongan angin yang berhembus menimbulkan arus dan riak atau gelombang laut yang kemudian pecah dan merambat di daerah pantai. Fenomena laut yang disebutkan ini, saat mendekati pantai akan berubah menjadi arus susur pantai arus meretas pantai (Dahuri et al., 1996). Secara sederhana arus gelombang dapat didefinisikan sebagai gangguan yang terjadi di permukaan air (Gross, 1993).

Arus adalah gerakan air yang diakibatkan oleh perpindahan berkala. Kombinasi antara arus dan pasut akan berperan di dalam transportasi sedimen pantai. Jika arus bergerak kuat dapat mengikis dan membawa sedimen sejauh tunggang air yang dibentuk di saat pasang tertinggi dan surut terendah (Kidson, 1982).

Sebagian dari laut Sulawesi, seperti yang dipetakan secara umum oleh Wyrtki (1961), bergerak sepanjang tahun dari arah barat daya dan barat. Meskipun demikian, keadaan lokal Teluk Amurang dan daratan sekitarnya berpeluang merubah pola tersebut saat terjadi pergerakan angin darat dan angin laut, demikian pula 
dengan perubahan debit air dari sejumlah sungai yang bermuara di teluk ini.

Gelombang merupakan suatu fenomena alam yang selalu terjadi di laut. Secara sederhana gelombang adalah gerak turun naiknya air laut (Kramadibrata 2002). Sedangkan menurut Dahuri et al. (1996), gelombang yang ditemukan di permukaan laut pada umumnya terbentuk karena adanya proses alih energi dari angin ke permukaan laut.

Pasut merupakan suatu fenomena naik turunnya muka air laut yang disertai oleh adanya gerakan horisontal dari massa air laut secara periodik. Gerak horisontal massa air laut ini disebut arus pasut. Pasut timbul karena pengaruh gaya tarik benda-benda langit (terutama bulan dan matahari) terhadap bumi. Mekanisme

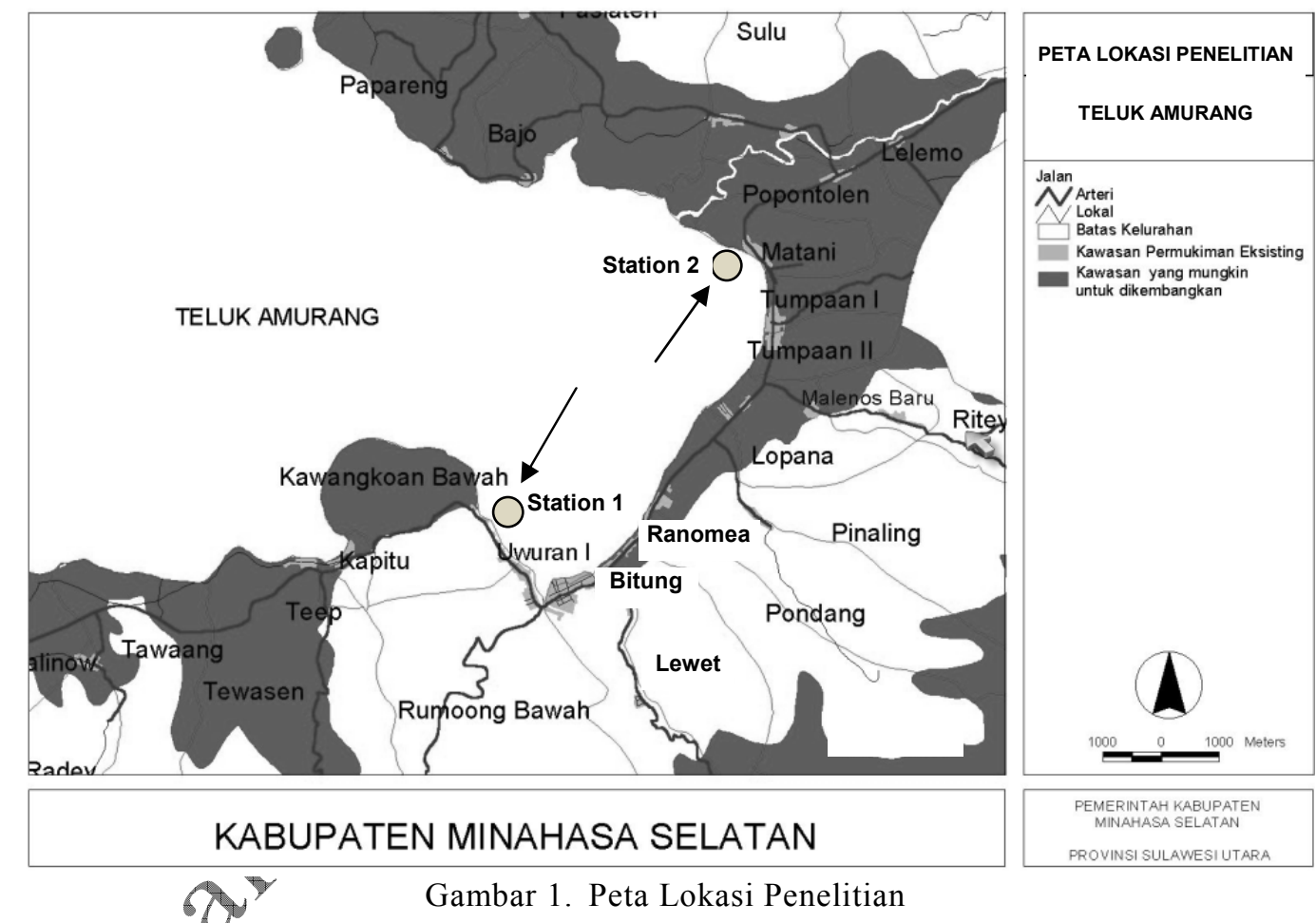

\section{METODOLOGI PENELITIAN}

Lokasi penelitian berada di lokasi perairan Teluk Amurang Kabupaten Minahasa Selatan 'tetak Geografis $1^{\circ} 11^{\prime} 00^{\prime \prime}-1^{\circ} 16^{\prime} 00^{\prime \prime} \mathrm{LU}$ dan $124^{\circ} 32^{\prime} 00^{\prime \prime}-124^{\circ} 36^{\prime} 00^{\prime \prime B T}$. Stasiun 1 berlokasi di Kelurahan Kawangkoan Bawah Kecamatan Amurang Barat, pada sisi barat daya teluk Amurang (1'12'39'LU-124 32'48'BT) dan stasiun 2 di Desa Matani Kecamatan Tumpaan (1 ${ }^{\circ} 15^{\prime} 49^{\prime \prime}$ LU-1243' $16^{\prime \prime}$ 'BT).

Waktu pelaksanaan pada Bulan September 2005. Pengamatan dilakukan pada periode Bulan Mati (5-6 September), periode Kuartir 1 (12-13 September), periode purnama (19-20 terbentuknya dapat dijelaskan dari teori pasut keseimbangan (Watimury, 2001). Untuk dapat memanfaatkan kawasan pesisir serta sumberdaya di dalamnya secara optimal dan lestari, maka salah satu yang perlu dilakukan adalah penelitian tentang kajian fisik oseanografi seperti gelombang dan arus laut serta karakteristik pasut di perairan tersebut.

Tujuan penelitian ini adalah mengetahui, mengukur dan menganalisis karakteristik arus dekat pantai (kecepatan dan arah arus), gelombang (energi gelombang) dan keadaan pãsut di perairan Teluk Amurang menúut-période umur bulan yang berbeda (purnama, Kuartir 1, bulan mati dan kuartir 3). 
pasut diilustrasikan dalam bentuk grafik pasut dan vektor batang. Sedangkan untuk arus diilustrasikan dalam gambar mawar arus dan vector stick plot.

Analisa data untuk melihat besarnya total energi gelombang dilakukan dengan mengacu pada formula yang dikembangkan oleh Pond dan Picard (1983) yaitu:

$$
\mathrm{E}_{\mathrm{Tot}}=\frac{\rho \cdot \mathrm{g} \cdot \mathrm{H}^{2} \cdot \mathrm{L}}{8}
$$

Dimana: $\mathrm{E}=$ Energi total joule

$\rho=$ Densitas air laut $\left(\mathrm{kg} / \mathrm{m}^{3}\right)$ yang merupakan fungsi dari salinitas dan temperatur (massa jenis air laut $1,025 \mathrm{~kg} / \mathrm{m}^{3}$ ).

$\mathrm{g}=$ Percepatan gravitasi bumi $(9,8 \mathrm{~m} / \text { detik })^{2}$.

$\mathrm{H}=$ Tinggi gelombang

$\mathrm{L}=$ Panjang gelombang

\section{HASIL DAN PEMBAHASAN}

\section{Keadaan Umum Teluk Amurang Arah dan kecepatan Arus}

Arus untuk stasiun 1 pada periode bulan mati (Gambar 2) memiliki kecepatan arus permukaan maksimum 0,95 knot ke arah $280^{\circ}$ (Barat), sedangkan kecepatan arus minimum adalah 0,19 knot ke arah $20^{\circ}$ TL (Timur Laut).

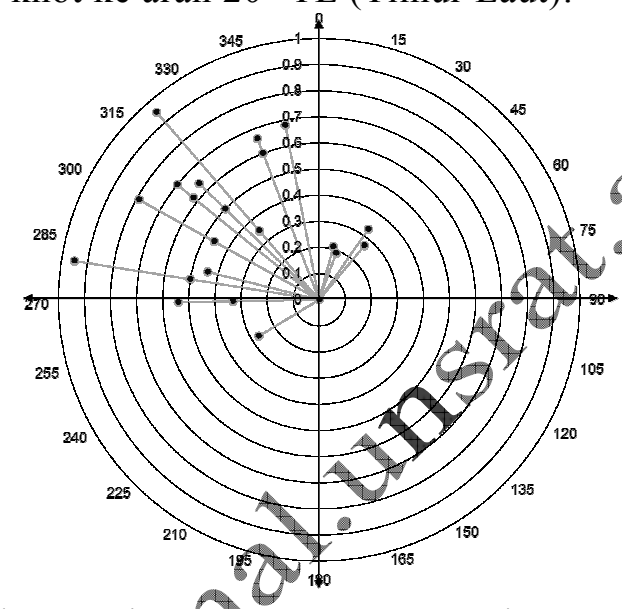

Gambar 2. Diagram Mawar Arus Stasiun 1 Saat Periode Bulan Mati.

pada periode bulan Kuartir 1 stasiun 1 (Gambar 3) kecepatan arus permukaan maksimum adalah 0,89 knot menuju ke arah $280^{\circ} \mathrm{BL}$ (Barat Laut), sedangkan kecepatan arus minimumnya adalah 0,25 knot menuju ke arah $28^{\circ}$ UTL (Utara Timur Laut).

Periode bulan purnama stasiun 1 (Gambar 4) kecepatan maksimum adalah 0,54 knot ke arah $25^{\circ}$ UTL (Utara Timur Laut) sedangkan kecepatan arus minimum adalah 0,17 knot ke arah $60^{\circ}$ UTL (Utara Timur Laut).

Pada periode bulan Kuartir 3 (Gambar 5) kecepatan arus maksimum adalah 0,68 knot ke arah $138^{\circ} \mathrm{Tg}$ (Tenggara) dan kecepatan arus minimum adalah 0,21 knot ke arah $190^{\circ} \mathrm{S}$ (Selatan).

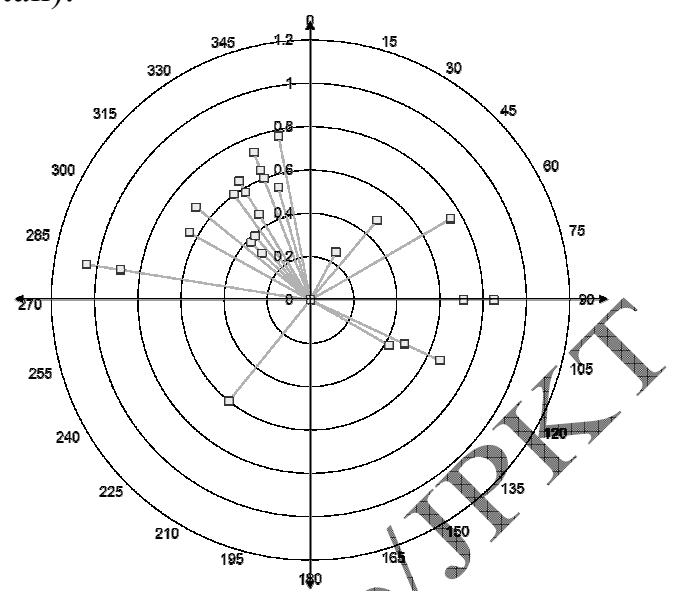

Gambar 3. Diagram Mawar rus Stasiun 1 Saat Periode Bulan ary.

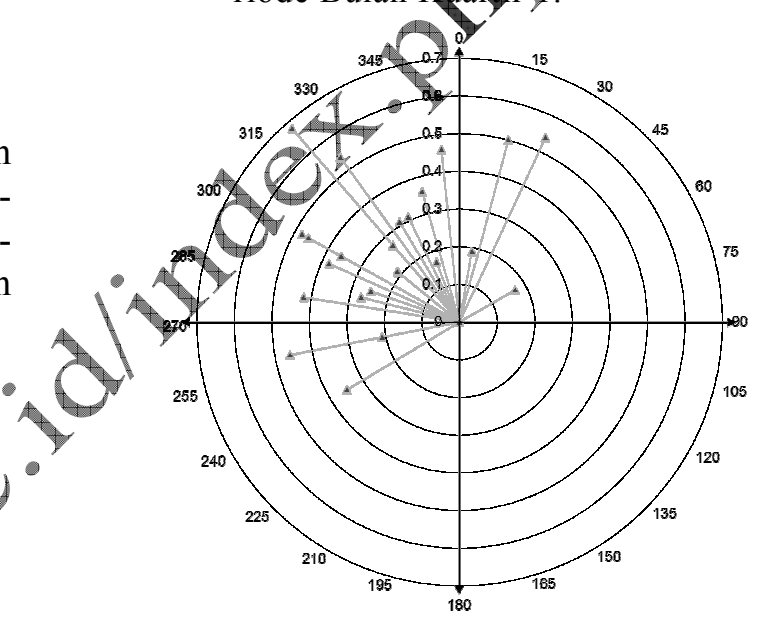

Gambar 4. Diagram Mawar Arus Stasiun 1 Saat Periode Bulan Purnama.

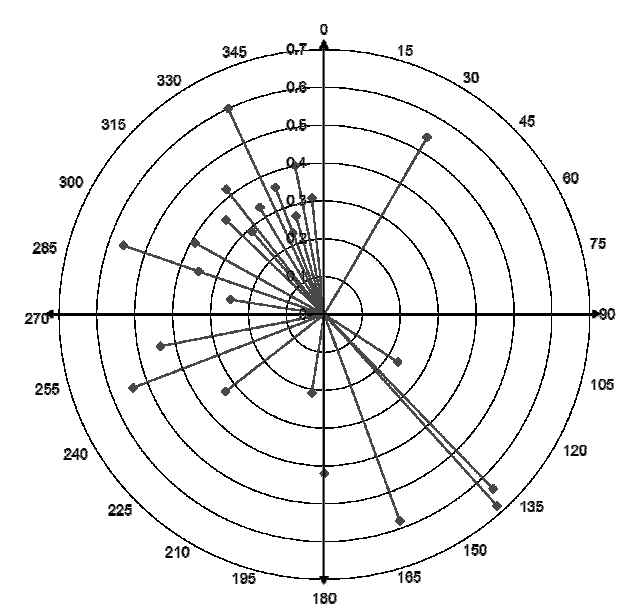

Gambar 5. Diagram Mawar Arus Stasiun 1 Saat Periode Bulan Kuartir 3.

Hasil penelitian arus permukaan untuk stasiun 2 (Gambar 6) pada periode bulan mati kecepatan arus maksimum 0,42 knot ke arah $100^{\circ} \mathrm{TTg}$ (Timur Tenggara), sedangkan kece- 
patan arus permukaan minimum adalah 0,17 knot ke arah $290^{\circ} \mathrm{BBL}$ (Barat Barat Laut).

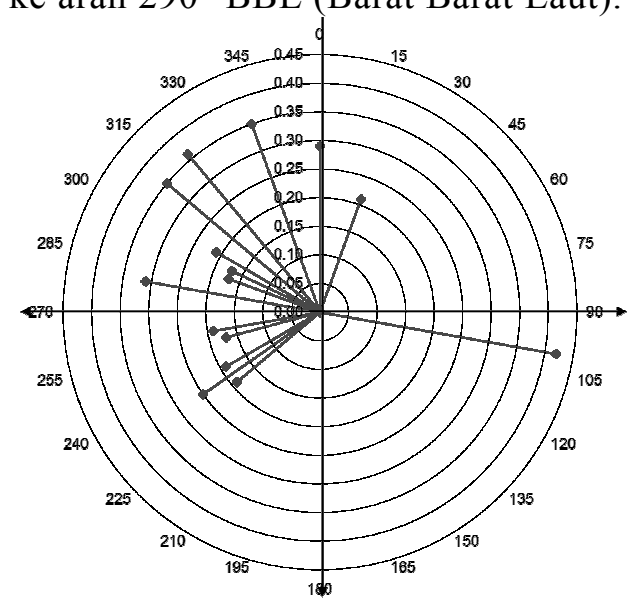

Gambar 6. Diagram Mawar Arus Stasiun 2 Saat Periode Bulan Mati

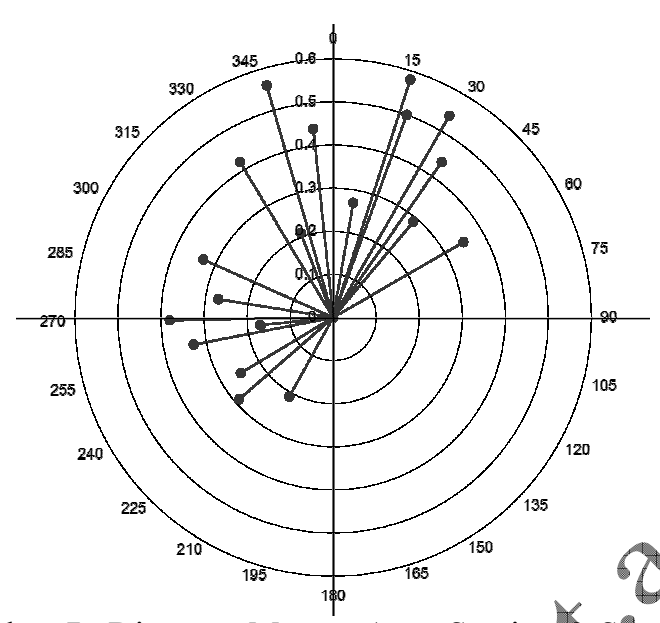

Gambar 7. Diagram Mawar Arus Stasiun 2 Såat Periode Bulan Kuartir 1

Pada periode bulan Kuâtił 1 (Gambar 7) kecepatan arus maksimun 58 knot ke arah $18^{\circ}$ UTL (Utara Timur Laut), sedangkan kecepatan arus minimumnya adalah 0,17 knot ke arah $265^{\circ} \mathrm{B}$ (Barat)

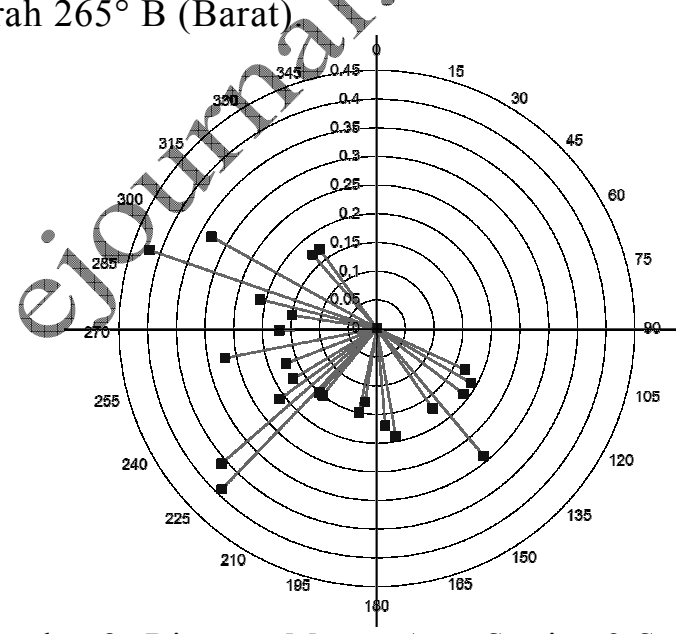

Gambar 8. Diagram Mawar Arus Stasiun 2 Saat Periode Bulan Purnama
Pada periode bulan purnama (Gambar 8) kecepatan arus permukaan maksimum adalah 0,42 knot ke arah $290^{\circ} \mathrm{BBL}$ (Barat Barat Laut) sedangkan kecepatan arus minimum adalah 0,13 knot ke arah $190^{\circ} \mathrm{S}$ (Selatan).

Pada periode bulan Kuartir 3 (Gambar 9) kecepatan arus max 0,78 knot ke arah $250^{\circ}$ BBD (Barat Barat Daya), sedangkan kecepatan arus permukaan minimumnya adalah 0,25 knot ke arah $150^{\circ} \mathrm{Tg}$ (Tenggara).

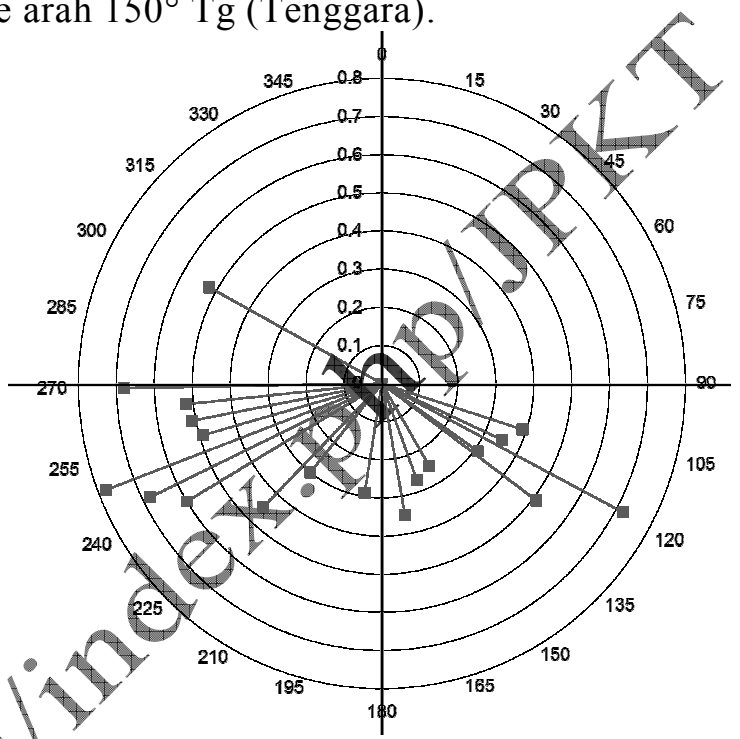

Gambar 9. Diagram Mawar Arus Stasiun 2 (Dua) Menurut Periode Bulan Kuartir 3

- Tabel 1. Hasil Analisis Data Pengamatan Arus.

\begin{tabular}{|c|c|c|c|c|}
\hline \multirow{2}{*}{ Peubah } & \multicolumn{4}{|c|}{ Waktu Pengamatan (Stasiun 1) } \\
\hline & Bulan mati & Kuartir I & Purnama & Kuartir 2 \\
\hline Kec. arus maks. (knot) & 0,95 & 1.05 & 0.68 & 0.68 \\
\hline Kec. arus min. (knot) & 0.19 & 0.25 & 0.17 & 0.21 \\
\hline Arah arus dominan & $320^{\circ}$ & $330^{4}$ & $320^{\circ}$ & $270^{\circ}$ \\
\hline \multirow{2}{*}{ Peuhah } & \multicolumn{4}{|c|}{ Wakte Pengamatan(Stasien 2) } \\
\hline & Bulan mati & Kuartir I & Purnama & Kuartit 2 \\
\hline Kec. arus maks. (knot) & 0,42 & 0,58 & 0.42 & 0,78 \\
\hline Kec. arus min. (knot) & 0.17 & 0.17 & 0.13 & 0.25 \\
\hline Arah arus dominan & $240^{\circ}$ & $230^{\circ}$ & $290^{\circ}$ & $240^{\circ}$ \\
\hline
\end{tabular}

Untuk stasiun 1 dan stasiun 2 perairan Teluk Amurang kecepatan arus senantiasa berubah-ubah di mana kecepatan arus yang terukur bervariasi antara 0,13-1,05 knot (Tabel 1).

\section{Pengukuran Gelombang}

Berdasarkan hasil penelitian Energi Total Gelombang untuk stasiun 1 pada periode bulan mati, energi total gelombang sebesar 0,076 joule, sedangkan energi total gelombang maksimum adalah 0,406 joule. Pada periode bulan Kuartir 1, energi total gelombang adalah 0,18 joule serta energi total gelombang maksimum adalah 0,7 joule. Untuk periode bulan purnama, energi total gelombang adalah 0,057 joule serta energi total gelombang maksimum adalah 0,163 
joule. Pada periode bulan Kuartir 3, energi total gelombang adalah 0,73 joule dan energi total gelombang maksimum adalah 2,12 joule.

Pada stasiun 2 pada periode bulan mati, energi total gelombang adalah 0,364 joule serta energi total gelombang maksimumnya adalah 1,28 joule. Pada periode bulan Kuartir 1, energi total gelombang adalah 0,813 joule dan energi total gelombang maksimumnya adalah 3,35 joule. Pada periode bulan purnama, energi total gelombang adalah 0,13 joule dan juga energi total gelombang maksimumnya adalah 1,4 joule pada periode bulan Kuartir 3, energi total gelombang adalah 0,73 joule, energi total maksimumnya 3,16 joule.

Tabel 2. Hasil Analisis Data Gelombang.

\begin{tabular}{lcccc}
\hline \multirow{2}{*}{ Parameter } & \multicolumn{4}{c}{ Waktu Pengamatan (Stasiun 1) } \\
\cline { 2 - 5 } & Bulan mati & Kuartir 1 & Purnama & Kuartir 2 \\
\hline Periode Gelombang & 1,856 & 1,769 & 2,12 & 2,516 \\
Tinggi Gelombang & 0,077 & 0,121 & 0,063 & 0,207 \\
Kec. Gelombang & 5,42 & 5,42 & 5,42 & 5,42 \\
Kedalaman (meter) & 3 & 3 & 3 & 3 \\
Panjang Gelombang & 10,06 & 9,59 & 11,49 & 13,64 \\
E tot Gel (joule) & 0,076 & 0,18 & 0,057 & 0,73 \\
\hline \multicolumn{1}{c}{ Parameter } & \multicolumn{3}{c}{ Waktu Pengamatan (Stasiun 2) } \\
\cline { 2 - 5 } & Bulan mati & Kuartir 1 & Purnama & Kuartir 2 \\
\hline Periode Gelombang & 2,159 & 2,666 & 1,782 & 2,720 \\
Tinggi Gelombang & 0,174 & 0,234 & 0,116 & 0,220 \\
Kec. Gelombang & 4,43 & 4,43 & 4,43 & 4,43 \\
Kedalaman (meter) & 2 & 2 & 2 & 2 \\
Panjang Gelombang & 9,56 & 11,81 & 7,9 & 12,05 \\
E tot Gel (joule) & 0,364 & 0,813 & 0,13 & 0,73 \\
\hline
\end{tabular}

\section{Penelitian Pasut}

Keadaan Pasut di perairan teluk Amurang berdasarkan umur bulan menunjukkan adanya perbedaan yang tidak begitu mencolok, antara daerah Kawangkoan Bawah (stasiun 1) dan Matani (stasiun 2). Perbedaan fase demikian diduga karena adanya interverensí gelombang balik dari pantai sekitar pesisir laut teluk Amurang. Walaupun demikian dapat dikatakan bahwa sifat pasut padakedua tempat itu sama. Hasil penelitian kedua tempat di daerah ini menunjukkan bahwa tipe pasut perairan Teluk Amurang mempunyâi tipe campuran condong ke harian ganda atau semidiurnal, yaitu dalam sehari semálam terdapat 2 kali pasang dan 2 kali surut dengan kisaran yang berbeda.

Pada periode Bulan Mati, surut terendah di Stasiun 1 terjadi pada pukul 13.00 dan 01.00, sedangkan pasang tinggi ditemui pada pukul 19.00 dan 07.00 dan nilai MSL (Mean Sea Level) adalah $121,52 \mathrm{~cm}$ yaitu nilai rata-rata permukaan air. Pada periode Kuartir 1 surut terendah terjadi pada pukul 15.00 dan 09.00 sedangkan pasang tertinggi terjadi pada pukul 00.00 dan nilai MSL adalah $143 \mathrm{~cm}$. Untuk periode purnama surut terendah terjadi pada pukul 13.00 untuk siang hari dan malam hari terjadi pada pukul 01.00 serta pasang tinggi terjadi pada pukul 19.00 untuk malam dan untuk siang pukul 07.00 dan MSLnya adalah $134,24 \mathrm{~cm}$. Pada periode Kuartir 3 surut terendah terjadi pada pukul 10.00 dan 11.00 , sedangkan pasang tertinggi terjadi pada pukul 03.00 serta nilai MSLnya adalah $123,12 \mathrm{~cm}$.

Tabel 3. Hasil Analisis Data Pasut.

\begin{tabular}{|c|c|c|c|c|}
\hline \multirow{2}{*}{ Peubah } & \multicolumn{4}{|c|}{ Waktu Pengamatan (Stasiun 1) } \\
\hline & Bulan mati & Kuartir I & Purnama & Kuartir 2 \\
\hline Tunggang air & 197,00 & 77,00 & 215,00 & 84,00 \\
\hline MSL & 121.52 & 143.00 & 134.24 & 123,12 \\
\hline HHWL. & 223,00 & 188,00 & 240,00 & 156,00 \\
\hline LLWL & 26,00 & 111,00 & 25,00 & 72,00 \\
\hline \multirow{2}{*}{ Peubah } & \multicolumn{4}{|c|}{ Waktu Pengamatan (Stasiun 2) } \\
\hline & Bulan mati & Kuartir I & Purnama & Kuartir 2 \\
\hline Tunggang air & 197,00 & 76.00 & 218.00 & 81.00 \\
\hline MSL. & 140,80 & 144.28 & 135,20 & 133,32 \\
\hline HHWL & 245,00 & 188,00 & 245.00 & 166,00 \\
\hline LLWL & 48,00 & 112,00 & 27,00 & 85,00 \\
\hline
\end{tabular}
untuk lokasi besa Matani surut terendah terjadi pada jam 13.00 pada siang hari dan 01.00 pada makan hari dan pasang tertinggi terjadi pada pukûl 19.00 pada malam hari dan siang jam 07.00 dan nilai MSLnya adalah 140,8cm. Untuk periode Kuartir 1 surut terendah terjadi pada - pukul 15.00 dan 09.00 dan pasang tertinggi terjadi pada pukul 00.00 dan MSLnya adalah $144,28 \mathrm{~cm}$. Pada periode purnama surut terendah terjadi pada pukul 13.00 dan 01.00 serta pasang tertinggi terjadi pada 19.00 dan 07.00 dan MSLnya adalah $135,2 \mathrm{~cm}$. Pada periode Kuartir 3 surut terendah terjadi pada pukul 11.00 sedangkan pasang tinggi terjadi pada pukul 03.00 dan nilai MSLnya adalah $133,32 \mathrm{~cm}$.

\section{KESIMPULAN}

Arah dan kecepatan arus untuk stasiun Kawangkoan Bawah banyak dipengaruhi faktor sungai Ranoyapo, pasut dan umur bulan. Arus cenderung bergerak menyusur pantai ke arah Laut (periode bulan mati) dan Utara Barat Laut (periode bulan Purnama). Arah dan kecepatan arus untuk stasiun Matani banyak dipengaruhi faktor topografi, pasut serta umur bulan. Arus cenderung bergerak menyusur pantai ke arah Barat Barat Daya (periode bulan Kuartir 3) dan Barat Laut (periode bulan purnama).

Besar energi total gelombang di Kawangkoan Bawah lebih kecil dibandingkan dengan Matani dengan besaran energi gelombang maksimum 0,813 joule (periode bulan Kuartir 
1). Untuk pasut memiliki tipe campuran condong ke harian ganda atau Semidiurnal dengan MSL maksimum 144,28 cm.

\section{DAFTAR PUSTAKA}

Dahuri R, Rais J, Ginting S dan Sutepu MJ. 2008. Pengelolaan Sumberdaya Wilayah Pesisir dan Lautan secara Terpadu. PT. Pradaya Paramita. Jakarta. 328 hal.

Gross GM. 1993. Oseonografi. Sixth Edition. Prentice Hall, Inc. New Jersey.

Kidson C. 1982. Sediment Transport. Hotinson Ross Publishing Company. Pensylvania.

Kramadibrata S. 2002. Perencanaan Pelabuhan. Institut Teknologi Bandung.

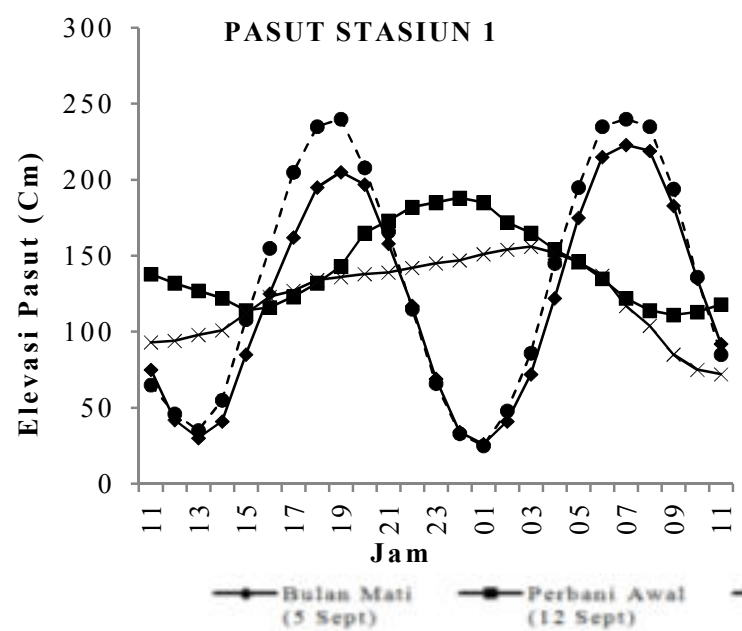

Gambar 10. Pasut Berdasarkan Periode Bułăn Mati Hingga Perbani Akhir Pada Stasiun 1 dan 2.
Manengkey H. 2010. Kandungan Bahan Organik Pada di Perairan Teluk Buyat dan Sekitarnya. J. Perikanan dan Kelautan Tropis. 6 (3): 114-119.

Pond S, Pichard. 1978. Dinamic Oceanography. $2^{\text {nd }}$ Edition.

Waftimury DL. 2001. Analisis Karakteristik Energi Gelombang. Fakultas Perikanan Universitas Patimura. Ambon.

Wyrtki K. 1961. Physical Oceanography Of South East Asean Waters. Naga Report Vol. 2 The University of California. Scripps Institution of Oceanography La Jolla. California.
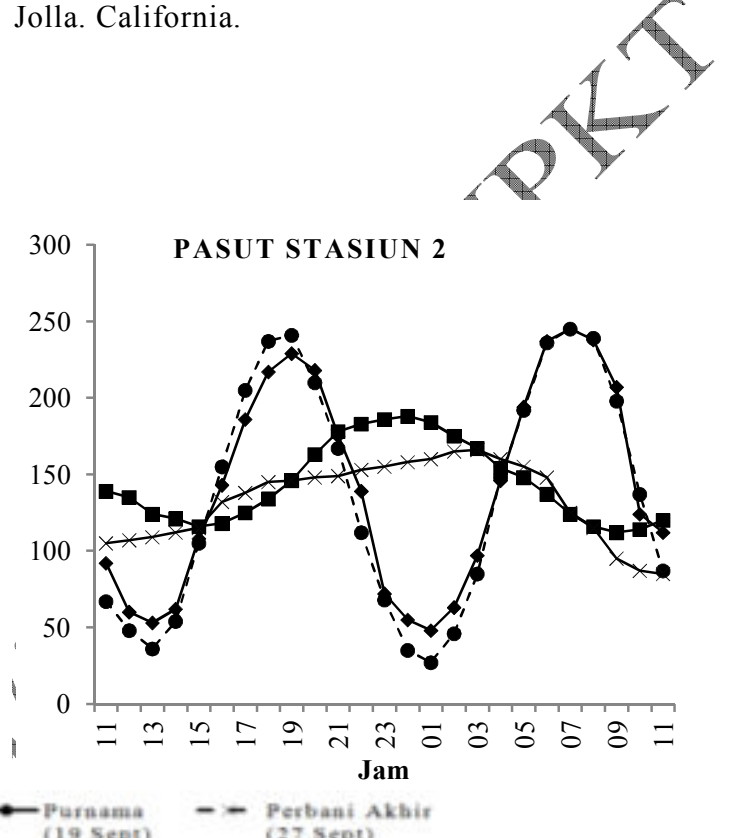